\title{
Production of Recombinant Proteins in Milk of Transgenic and Non-transgenic Goats
}

\author{
Raylene Ramos Moura, Luciana Magalhães Melo and Vicente José de Figueirêdo Freitas* \\ Laboratório de Fisiologia e Controle da Reprodução; Faculdade de Veterinária; Universidade Estadual do Ceará, \\ Fortaleza - CE - Brasil
}

\begin{abstract}
Among all the transgenic mammalians produced so far, goats have represented an excellent model of transgenesis when considering the factors such as the market demand for protein, volume of milk produced per lactation and reproductive rate. Various recombinant proteins have been obtained from the transgenic and non-transgenic goats, and among these, human antithrombin, produced by the transgenic goats, was the first recombinant protein of animal origin to be released as a drug for the clinical use in humans. This review reports the aspects inherent to the production of recombinant proteins in the goats, from the production of the animal bioreactors up to the expression of these proteins in their milk.
\end{abstract}

Key words: transgenesis, goat, recombinant protein, milk

\section{INTRODUCTION}

Human proteins have been utilized in medicine worldwide, and for some time, their supply was limited due to the few sources for their extraction (Clark, 1998). With the advent of genetic engineering, this reality changed, because the genes of interest could be isolated, inserted into expression vectors and transferred to the cells or organisms that could be turned into producers of proteins on an industrial scale (Houdebine, 2003). The first attempts at the production of therapeutic proteins from the cloned genes were from the microorganisms. However, some human proteins were synthesized only in small amounts, others became insoluble making their purification difficult. In addition, the products of gene expression can be immunogenic and can have little biological activity due to incorrect post- translational processing (Kues and Niemann, 2004). As an alternative, another expression system, such as animal cells, has been used, although it is a costly process and not very profitable. Since 1982, with the development of the first mouse expressing elevated levels of the human growth hormone (Palmiter et al., 1982), it was found that animals could be utilized as bioreactors. Later, various transgenic animals were obtained in different species: rabbits, pigs and sheep (Hammer et al., 1985), goats (Ebert et al., 1991) and cattle (Krimpenfort et al., 1991). According to Clark (1998), for the production of recombinant proteins, some aspects should be considered in the choice of the bioreactor species, such as the market demand, volume of milk produced per lactation and reproductive rate. Of all the transgenic mammalian bioreactors already produced, goats (Capra hircus) have represented

*Author for correspondence: vjff@pq.cnpq.br 
an excellent model for transgenesis, since the production of founder animals and operating costs are significantly easier to manage compared to cattle. The aim of this review was to examine the aspects inherent to the production of recombinant proteins in transgenic goats, from obtaining the founder animals up to the expression of these proteins in milk. In addition, the production of these proteins in non-transgenic goats is considered.

\section{Mammary gland as bioreactor}

The mammary glands are apocrine exocrine cutaneous glands of the tubulo-alveolar composition type and their secretory units consist of alveoli that lead to small excretory ducts. The groups of secretory units form lobules that are later grouped into larger structures called lobes, forming the mammary parenchyma.

The alveoli are the fundamental secretory units of milk and are composed of epithelial cells capable of synthesizing the fats, carbohydrates and proteins, expelling the product to the inside the lumen of the alveoli. The proteins secreted by the mammary gland are grouped into two classes, caseins and serum proteins. According to Park et al. (2007), ruminants secrete mainly four caseins $(\alpha s 1, \alpha s 2, \beta$ and $\kappa)$ and two serum proteins ( $\beta$ lactoglobulin and $\alpha$-lactoalbumin). The genes that encode these proteins are in simple copies and are transcribed at high levels, specifically in the mammary gland during the pregnancy and lactation (Clark, 1998). Therefore, pioneer works in the 1980s explored the capacity of the production of recombinant proteins in the milk of transgenic animals (Gordon et al., 1987; Simmons et al., 1987). Thus, promotors and regulatory regions of genes of specific milk proteins were utilized to direct the gene expression in the mammary gland (Maga and Murray, 1995).

The mammary gland can be currently considered the best bioreactor available (Colman, 1996), since milk represents a source of raw material, unprocessed, safe, abundant, renewable, easy to obtain and well accepted by the public. Besides, extensive studies have demonstrated the possibility of the production of a great variety of recombinant proteins in milk.

\section{Gene constructions for expression in mammary gland}

Gene construction is a fundamental element in the production of transgenic animals and consists, generally, of a promotor region, a gene that encodes the protein of interest and other regulatory elements to optimize gene expression (Maga and Murray, 1995). The transgene or exogenous gene that codes for the protein of interest can be derived from another animal of the same species, different species or even of other kingdoms such as bacteria, yeasts or plants (Pesqueiro et al., 2007).

According to Keefer (2004), the selection of this gene should be based on social, scientific and economic factors. Thus, is there a market niche for the protein? If the recombinant protein could be used to treat a disease, can clear scientific endpoints be measured during the clinical trials? Can sufficient amounts of the purified protein be produced to meet the market requirements; if so, at what cost?

The expression of the transgene in the mammary gland requires the use of promotors and regulatory regions of the genes of milk proteins, that is, sequences that direct the gene expression only for the mammary gland during lactation (Maga and Murray, 1995). In this manner, it is expected that the expression of the recombinant protein would be limited to the mammary gland to avoid the deleterious effects on the health of the animal. Promotors are sequences of a few kilobases located close to the 5' end of the transcribed region of the gene (Houdebine, 2003). In goats, various regulatory sequences of milk specific genes were already isolated and verified in the production of transgenic animals, such as a murine WAP (Ebert et al., 1991; Baldassarre et al., $2004 b$ ), goat $\beta$-casein (Ko et al., 2000; Parker et al., 2004), bovine $\beta$-casein (Lee et al., 1997; Huang et al., 1998) and goat and bovine $\alpha$ s1casein (Freitas et al., 2007).

The expression levels of recombinant proteins (Table 1) vary from one bioreactor to another, which can be related to various factors, such as the expression vector; method utilized for the transfer of genetic material; number of copies and site of insertion of the transgene (Rosen et al., 1996). 
Table 1 - Expression level, from highest to lowest, of recombinant human proteins in the milk of transgenic goats.

\begin{tabular}{lccl}
\hline \multicolumn{1}{c}{ Gene } & Promoter & Expression level $\mathbf{( m g / m L )}$ & \multicolumn{1}{c}{ Reference } \\
\hline Monoclonal antibodies & goat $\beta$-casein & 14.0 & Pollock et al., 1999 \\
Antithrombin & goat $\beta$-casein & $0.09-12.5$ & Zhou et al., 2005 \\
Butyrylcholinesterase & goat $\beta$-casein & $0.1-5.0$ & Huang et al., 2007 \\
$\alpha$-fetoprotein & goat $\beta$-casein & $0.6-1.1$ & Parker et al., 2004 \\
Lactoferrin & goat $\beta$-casein & 0.77 & Zhang et al., 2008 \\
Lysozyme & cattle $\alpha$ s1-casein & 0.27 & Maga et al., 2006a \\
G-CSF $^{\text {a }}$ & cattle and goat $\beta$-casein & 0.07 & Freitas et al., 2010 \\
GH $^{\text {b }}$ & goat $\beta$-casein & 0.07 & Lee et al., 2006 \\
G-CSF $^{\text {a }}$ & goat $\beta$-casein & 0.05 & Ko et al., 2000 \\
Factor IX & cattle $\beta$-casein & $9.5 \times 10^{-5}$ & Huang et al., 1998 \\
\hline
\end{tabular}

${ }^{\mathrm{a}}$ Granulocyte Colony-Stimulating Factor; ${ }^{\mathrm{b}}$ Growth Hormone

\section{Post-translational processing in the mammary gland}

The biological activity of many proteins is dependent on appropriate post-translational processing, including the removal of the signal peptide, formation of disulfide bonds, modifications of amino acids, proteolytic processing and addition of subunits. Bacteria possess limitations in their ability to carry out the post-translational modifications of proteins necessary for many functions, while some eukaryotic systems, such as yeasts, filamentous fungi and unicellular algae, do not have adequate post-translational processes, yielding recombinant products with little biological activity or immunogenicity (Dyck et al., 2003). Cultured mammalian cells and transgenic animals are utilized for the production of recombinant proteins when complex post-translational modifications are necessary for bioactivity of the protein (Clark, 1998).

One of the commonest and least well understood posttranslational modifications of proteins is their glycosylation. Human glycoproteins are glycosylated with a bewilderingly heterogeneous array of complex $\mathrm{N}$ - and O-linked glycans, which are the product of the coordinated activity of enzymes resident in the endoplasmic reticulum and Golgi apparatus of the cell. Glycosylation of proteins is highly regulated and changes during differentiation, development, under different conditions and in disease. The glycosylation of recombinant proteins, especially those destined for potential administration to human subjects is of critical importance. Glycosylation profoundly affects biological activity, function, clearance from circulation, and crucially, antigenicity (Brooks, 2004).
A DNA sequence provides all of the information necessary for a cell to produce a recombinant protein with the same amino acid sequence as the native protein but it does not dictate exactly how that protein will be glycosylated. Therefore, using a human DNA sequence does not guarantee that the molecule will be glycosylated as it is when synthesized by the human bodies. The peptide sequence may determine where glycosylation is added to the protein but the mix of glycosyltransferases, within the cell the protein is expressed in and even the conditions under which those cells are cultured will determine what oligosaccharide structures are added to the molecule (Raju et al., 2003; Betenbaugh et al., 2004).

Covalent binding between the sugars and the peptide chain is a central part of the structure of glycoproteins. The main ones are: (1) N-glycosidic bonds, which occur between a residue of $\mathrm{N}$ acetylglycosamine (GlcNac) and the amino acid asparagine (Asn) of the polypeptide chain; (2) Oglycosidic bonds, which occur between a residue of $\mathrm{N}$-acetylgalactosamine (GalNac) and the $\mathrm{OH}$ group of serine (Ser) or threonine (Thr) of the polypeptide chain (Luboń et al., 1996).

Mammalian species are phylogenetically closest to human beings and can show common patterns of glycosylation. In general, the glycosylation found in human proteins secreted in the milk of transgenic animals has been similar to that of human plasma proteins (Meade et al., 1999). Cole et al. (1994) found that antithrombin III (AT III) and LAtPA (the long-acting form of human tissue plasminogen activator) expressed in the goat milk had some N-acetylgalactosamine (GalNAc) replacing the $\mathrm{N}$ - group of galactose on 
oligosaccharide complexes. Both the recombinant AT III and LAtPA were shown to be more fucosylated than their recombinant or plasma counterparts. Denman et al. (1991) observed that significantly lower levels of galactose, Nacetylglucosamine and sialic acid were present in LAtPA from transgenic goats, when compared to proteins produced by the murine cell line $\mathrm{C} 127$ and Chinese hamster ovary cells ( $\mathrm{CHO})$.

Carboxylation is the introduction of a carboxyl group or carbon dioxide to form carboxylic acid (Bösze et al., 2008). Coagulation cascade factors dependent on vitamin $\mathrm{K}$ and regulatory proteins require the conversion of glutamic acid residues (Glu) into gamma-carboxyglutamic acid (Gla). Gla residues bind to calcium which is an essential cofactor for its activity, thereby making it possible for the adhesion of coagulation factors to cell surface phospholipids, accelerating the coagulation process. Species-specific differences were observed in the ability of mammary epithelial cells with respect to the carboxylation of recombinant proteins, and these differences can reflect the enzyme levels and/or specificity of the substrate (Luboń et al., 1996).

Proteolytic processing is also a very important post-translational modification, where it is the first step of protein maturation in which the signal peptide is removed. The signal peptides are short sequences (generally 13-30 amino acids) at the $\mathrm{N}$ terminal region of proteins, which direct the posttranslational transport of new proteins (synthesized in the cytosol) to certain organelles which promote this processing (Bösze et al., 2008).

Methods for the production of transgenic goats Transgenic goats have been obtained to date by pronuclear microinjection and somatic cell nuclear transfer (SCNT). Their main steps are presented in Figure 1.

Pronuclear microinjection is the traditional method for the production of transgenic goats, which generally consists of the microinjection of DNA into one of the pronuclei of the embryo, where it is necessary to utilize an inverted microscope. With the help of micromanipulators, the pronuclear embryo is held, while a micropipet containing the DNA construction (cerca of 500-5000 copies in 1$2 \mathrm{pL}$ ) penetrates the zona pelucida and the injection into one of the pronuclei is performed (Houdebine, 2003). Pronuclear microinjection should be done between 15 and $20 \mathrm{~h}$ after probable fertilization. Besides, due to the presence of cytoplasmic lipid drops, the goat embryos should be first submitted to centrifugation. This method shows a low efficiency. Generally, less than $10 \%$ of the offspring are transgenic (Baldassarre and Karatzas, 2004). In Brazil, the first goats were born from the microinjected embryos (Freitas et al., 2003) and, later the birth of the first transgenic goat in Latin America was achieved (Freitas et al., 2007).

SCNT, combined with molecular biology and cell culture methods, shows a variety of applications. Among the different areas, transgenesis is possibly the one that has benefited the most from the advances in this biotechnique in the sense of increasing the efficiency and reducing costs.

Since the birth of the sheep Dolly, the basic technology of SCNT continues to be the same. It consists of the transfer of the nuclei of donor cells to enucleated oocytes with later reconstruction of the embryo through the cell fusion. SCNT can produce transgenic animals through the transfection of nuclei with vectors of DNA expression or cloning of transgenic founder animals (Baldassarre and Karatzas, 2004).

In the SCNT method utilizing the transfection of the nuclei, exogenous DNA is randomly incorporated into the genome using selective pressure. Besides, transgenic cells can be completely characterized with respect to the integration region, number of copies integrated and integrity of the transgene before the nuclear transfer step. Although the capacity for development of the reconstructed embryos is low, the majority of the offspring are transgenic, making this technique much more efficient than pronuclear microinjection (Behboodi et al. 2005). 


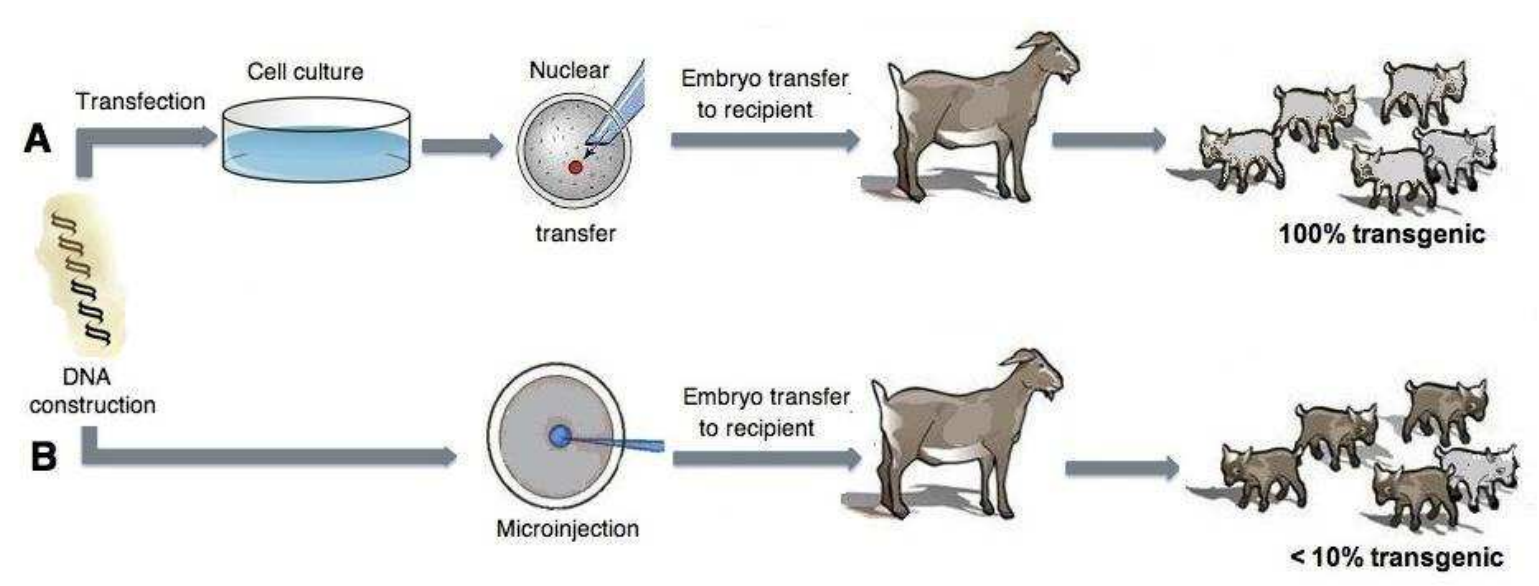

Figure 1 - Methods for producing transgenic goats: (A) somatic cell nuclear transfer (SCNT) and pronuclear microinjection (B).

\section{RECOMBINANT PROTEINS IN MILK OF TRANSGENIC GOATS}

\section{Alpha-fetoprotein}

Human $\alpha$-fetoprotein $(h \alpha F P)$ is a serum glycoprotein expressed at high levels in the fetal liver, but its concentration falls drastically after birth (Deutsch, 1991). Potential indications for its use include autoimmune diseases such as rheumatoid arthritis, multiple sclerosis, myasthenia gravis and psoriasis (Bösze et al., 2008). Transgenic goats expressing hoFP in milk were obtained by Parker et al. (2004). In this work, to avoid the incorrect glycosylation patterns of the protein, the glycosylation site was removed from the gene construction, since it was observed that its biological activity was not altered when the protein was not glycosylated. With the characterization of the recombinant protein, it was found that despite its structure being different, the pharmacokinetic properties appeared identical to those of the native protein.

\section{Malaria vaccine antigen}

Stowers et al. (2002) produced a candidate vaccine that showed the antigen MSP1 $1_{42}$ (Protein 1 of the surface of the merozoite of Plasmodium falciparium) in the milk of transgenic mice. Biological activity of this protein was tested in monkeys and it was found to be capable of protecting them against the agent. Behboodi et al. (2005) utilized the same expression vector for the antigen $\mathrm{MSP}_{42}$ of malaria. In this work, cloned transgenic goats expressing this protein in the nonglycosylated form produced milk over 100 days capable of generating the equivalent of five million doses of vaccine against malaria.

\section{Antithrombin III}

Antithrombin III (hAT-III) is a serum protein with antiinflammatory and anticoagulant properties (Murano et al., 1980). hAT-III inhibits the majority of the proteinases in blood coagulation, such as thrombin, activated factor $\mathrm{X}$, and, to a lesser degree, the activated coagulation factors, including IXa, XIa, XIIa, urokinase, trypsin, plasmin and calikrein (Quinsey et al., 2004). When bound to heparin, the inhibitory activity of AT in thrombin is accelerated 1000 times. Thus, AT shows a crucial role in the regulation of blood coagulation and the individuals with a deficiency of antithrombin run the risk of developing fatal blood clots (Quinsey et al., 2004).

In 2006, the recombinant form of hAT-III $\left(\right.$ Atryn $^{\circledR}$ ), produced by the goats, was approved for clinical use in the European market (Schmidt, 2006), and in 2009 in the U.S. (Kling, 2009). Edmunds et al. (1998) found that the specific activity of hAT-III produced by goat bioreactors was identical to that of plasma hAT (phAT). However, it showed an affinity for heparin four times greater than that of phAT. Transgenic goats for hAT-III, produced by nuclear transfer from fetal somatic cells, showed a high level of production and biological activity of the recombinant protein (Baguisi et al., 1999).

\section{Tissue plasminogen activator}

Human tissue plasminogen activator (htPA) is a serum protease that converts the pro-enzyme 
plasminogen into plasmin, a fibrinolytic enzyme capable of initiating the degradation of proteins of the extracellular matrix. Ebert et al. (1991) produced the first goat bioreactor that expressed htPA in milk. Besides, htPA with a variation in glycosylation, called long-acting plasminogen tissue activator (LAtPA), was obtained in goat milk (Ebert et al., 1994). Later, Baldassarre et al. (2004a) also obtained transgenic goats for htPA by pronuclear microinjection.

\section{Butyrylcholinesterase}

Human plasma butyrylcholinesterase (hBChE) is an enzyme that catalyzes the hydrolysis of esters of choline, including acetylcholine, having an important role in cholinergic neurotransmission and may be involved in other functions of the nervous system and neurodegenerative diseases (Darvesh et al., 2003). Huang et al. (2007) obtained transgenic goats expressing high levels of this protein in their milk, with possible utilization of recombinant $\mathrm{hBChE}$ in the prophylaxis or treatment of humans exposed to organophosphorus or chemical warfare agents (Lenz et al., 2010).

\section{Lactoferrin}

Lactoferrin (LTF) shows various biological activities such as antiviral, antitumor, antibacterial, antifungal, antiinflammatory and immunoregulatory properties (Varadhachary et al., 2004). Transgenic goats produced by the pronuclear microinjection by Zhang et al. (2008) secreted elevated levels of human LTF in milk. In addition, the biochemical and physico-chemical characteristics of recombinant human LTF were similar to those of the native protein.

\section{Factor IX}

Deficiencies in human factor IX (hF IX) are linked to chromosome $\mathrm{X}$ defects, which lead to the hemorrhagic disorders of hemophilia B. Thus, patients with this deficiency are dependent on replacement therapy for this factor. Huang et al. (1998) produced transgenic goats secreting hF IX in the milk and with approximately 50\% biological activity when compared to the native protein.

\section{Lysozyme}

Lysozyme shows antimicrobial properties and catalyzes the cleavage of glycosidic bonds between the $\mathrm{C}-1$ of $\mathrm{N}$-acetylmuramic acid (Mur2Ac) and the C-4 of N-acetyl-D-glucosamine (GlcNAc) in peptidoglycans of bacterial cell walls
(Maga et al., 2006b). The levels of lysozyme in the milk of dairy animals are 1600 to 3000 times less than that found in human milk. Lysozyme in milk can diminish bacterial growth, increasing the safety and storage time of milk and milk products. Besides, the presence of lysozyme in the udder can reduce the incidence of mastitis. Maga et al. (2006b) produced transgenic goats for human lysozyme, which showed a lower somatic cell count in milk, suggesting an improvement in the health of the animal's udder. Brundige et al. (2008) demonstrated that the consumption of pasteurized milk of transgenic goats for lysozyme by litters improved gastrointestinal health and protection against enteropathogenic infections.

\section{Human granulocyte colony-stimulating factor} Human Granulocyte Colony-Stimulating Factor (hG-CSF) is a hematopoetic growth factor that acts on the maturation of neutrophils, stimulating their phagocytic and chemotactic activities, besides being involved with the process of nuclear segmentation of the mature neutrophils (Basu et al., 2002). Human G-CSF is widely utilized in different forms of neutropenia, chemotherapeutically induced leukopenia and mobilization of progenitor cells for autologous or allogenic transplants (Welte et al., 1996). Transgenic goats secreting hG-CSF in milk have been already obtained in South Korea (Ko et al., 2000) and Brazil (Freitas et al., 2007; Freitas et al., 2010).

\section{Human growth hormone}

Human growth hormone (hGH) or somatotrophin is a polypeptide synthesized and secreted by the cells of the anterior hypophysis. hGH is one of the principal hormones required for post-natal growth and is absolutely essential for normal body development (Delitala et al., 1988). Lee et al. (2006) produced a transgenic goat for $\mathrm{hGH}$, secreting this protein in the milk.

\section{Protein of spider silk}

The protein fibers of spider silk are known for being natural materials with high tensile strength and toughness. Due to these properties, these fibers have been the target of studies for more than 40 years (Swanson et al., 2009). Some research has utilized transgenesis for the expression of recombinant proteins of spider silk from mammalian epithelial cells and from the milk of transgenic goats for potential uses in ballistic 
protection, aircrafts, medical devices, and automotive material, among others (Karatzas et al., 1999).

\section{Recombinant proteins in milk of non-transgenic goats}

Direct in vivo transdution in the mammary gland has been proposed as a rapid, less costly, alternative method when compared with other techniques for the expression of exogenous genes (Schanbancher and Amstutz, 1997). This method consists of a direct infection of the mammary epithelium of an adult female utilizing viral vector with deficient replication. The procedure is simplified by the morphology of the mammary gland that allows direct communication of the alveolar ducts with the nipple. This facilitates the access to the epithelial cells without the need for a surgical procedure (Montesino and Toledo, 2006).

This technique can reduce the time to produce recombinant proteins from years to weeks (Bösze et al., 2008). Thus, using this method, it is possible to: (a) determine the efficiency of different promotors, removing the action of variables associated with the effect of the position or number of copies, (b) evaluate the functionality of gene constructions before producing the transgenic animals and (c) study the biological, chemical and physical characteristics of recombinant proteins expressed in the milk of different species at the same time (Sanchez et al., 2004). In goats, this technique was first proposed by Archer et al. (1994) who obtained hGH in milk. Later, various recombinant proteins were produced (Table 2).

Table 2 - Expression level, from highest to lowest, of recombinant human proteins in the milk of non-transgenic goats.

\begin{tabular}{llccl}
\hline Gene (Source) & Vector & Promoter & Expression level (mg/mL) & Reference \\
\hline Antithrombin III (human) & Adenovirus & CMV & 2.8 & Yang et al., 2009 \\
Growth hormone (human) & Adenovirus & CMV & 2.4 & Han et al., 2009 \\
Erythropoietin (human) & Adenovirus & CMV & 2.0 & Toledo et al., 2006 \\
Lactoferrin (human) & Adenovirus & CMV & 2.0 & Han et al., 2007 \\
E2-CSFV (swine) & Adenovirus & CMV & 1.2 & Toledo et al., 2008 \\
Growth hormone (human) & Adenovirus & CMV & 0.3 & Sánchez et al., 2004 \\
NGF- $\beta$ (human) & Adenovirus & CMV & 0.2 & Xiao et al., 2009 \\
Lysostaphin (bacterian) & Adenovirus & RSV & 0.02 & Fan et al., 2004 \\
Lysostaphin (bacterian) & Adenovirus & RSV & 0.001 & Fan et al., 2002 \\
Growth hormone (human) & Retrovirus & MoMLV & $6.0 \times 10^{-5}$ & Archer et al., 1994 \\
Factor IX (human) & Retrovirus & $\beta$-actina & $4.8 \times 10^{-5}$ & Zhang et al., 1997 \\
\hline
\end{tabular}

E2-CSFV: envelope glycoprotein of the classical swine fever virus; NGF- $\beta$ : Nerve Growth Factor Beta; CMV: citomegalovirus; RSV: Rous sarcoma virus; MoMLV: Moloney murine leukemia virus.

\section{Antithrombin III}

Recombinant hAT-III was also obtained from nontransgenic goats by Yang et al. (2009). The authors demonstrated that the established method was a pragmatic tool for the large-scale production of recombinant hAT-III, and this showed potential for substituting the commercial medication in the therapy of patients with disseminated intravascular coagulation.

\section{Erythropoetin}

Human erythropoetin (hEPO) is the glycoprotein responsible for stimulating the formation of erythrocytes, acting as a hormonal factor of mitotic stimulation and of differentiation, besides stimulating the production of erythrocytes from precursors in the cellular compartment of origin
(Lappin et al., 2002). Inappropriate low levels of serum EPO can be observed in the patients with cancer, rheumatoid arthritis, HIV infection, ulcerative colitis and sickle cell anemia. In goats, recombinant hEPO was produced by the direct infection of the mammary gland with adenoviral vectors (Toledo et al., 2006).

\section{Human nerve growth factor beta}

Human nerve growth factor beta (hNGF- $\beta$ ) is essential for the survival, growth and differentiation of peripheral and central nerves (Greene and Shooter, 1980). The use of NGF can repair the damaged nerves, prevent/treat retrograde neurological diseases such as Alzheimer's disease, and promote the differentiation of neuroblasts (Frade and Barde, 1998). Xiao et al. (2009) 
obtained by direct transduction, non-transgenic goats secreting recombinant hNGF- $\beta$ in their milk.

\section{Human factor IX}

This factor was also produced in the milk of nontransgenic goats utilizing retroviral vectors from direct transduction in the mammary lobule and the infusion of viral suspension into the mammary duct (Zhang et al., 1997). The peak of expression of $\mathrm{hF}$ IX in the milk of non-transgenic goats reached $4.8 \times 10^{-5} \mathrm{mg} / \mathrm{mL}$ and the protein proved to be biologically active.

\section{Growth hormone}

Han et al. (2009) obtained GH in the milk of nontransgenic goats for ten days, from the infusion of adenovirus into the mammary gland. Archer et al. (1994) and Sanchez et al. (2004) also reported on non-transgenic goats secreting $\mathrm{GH}$ utilizing the same method.

\section{Lactoferrin}

Han et al. (2007) obtained elevated expression levels of hLTF in the milk of non-transgenic goats after the infusion of adenovirus into the mammary gland. In this work, although the protein was expressed in a transient manner, when compared to the current transgenic technology, the method was shown to be one of the most economic and efficient ways of producing recombinant hLTF on a large scale.

\section{Lysostaphin}

Studies have shown lysostaphin as a therapeutic agent in the infections caused by staphylococci (Kumar, 2008). Goats have already been utilized for the production of active lysostaphin in milk by intramammary infusion of an adenoviral vector. Fan et al. $(2002,2004)$ detected lysostaphin in the milk of non-transgenic goats. However, these authors did not obtain results consistent with respect to bioactivity and duration of the expression of the recombinant protein, aiming to prevent and treat the staphylococcal infections in the mammary gland.

\section{E2-CSFV vaccine}

E2 is the major glycoprotein of the viral capsule, as a homodimer on the surface of the virus of the classic swine pest and represents the most significant target for the induction of the immune response in swine (Dong and Chen, 2007). E2 was expressed in the milk of goats transduced with adenoviral vectors directly in the mammary gland, and the recombinant protein was utilized for the immunization of pigs, which were then protected against a highly pathogenic strain of the classic swine pest (Toledo et al., 2008). Thus, this type of system can be an alternative for the production of veterinary vaccines.

\section{Transgenic vs non-transgenic goats}

High-level expression of recombinant protein in the goat mammary gland continues to be a desirable but still not easy goal. Drawbacks in this technology include the technically difficult procedure required and the length of time between incorporating foreign DNA and harvesting the exogenous protein. However, once a founder animal that has a stably integrated transgene and correctly expresses the gene has been produced, then propagation of a transgenic herd may be easily initiated (Keefer, 2004). On the other hand, the direct in vivo transduction of the mammary gland has been presented as a fast and inexpensive alternative to target the expression of a heterologous gene to the secretory mammary epithelial cells (Sánchez et al., 2004). Although these expression levels may be enough for certain basic studies, they must be improved when large amounts of recombinant proteins are required.

Thus, each of the methods has advantages and disadvantages and the choice of that will depend on both the purpose and the laboratory conditions.

\section{CONSIDERATIONS}

Since the production of the first transgenic goat in the world, in the beginning of the 1990s, this species has been utilized as a model for the production of recombinant proteins. During this time, besides having acquired a broad knowledge of the various aspects that influence the production of transgenic animals, the success rates continued to be low. Nonetheless, various proteins, mainly the human ones, have been produced, purified and characterized. Some of these proteins are already in clinical trials, and one of them has been released as a drug for clinical use in humans. In this manner, the synthesis of human recombinant proteins by goat bioreactors presents an alternative, renewable and profitable source, compared to other standard systems for the 
expression of proteins. In addition, with the production of the first transgenic goat in Brazil, it is expected that the country can join the select group of countries dominating this technology and will be able to reduce the costs of the production of recombinant proteins of interest in human health.

\section{ACKNOWLEDGEMENTS}

R.R. Moura carried out her doctorate study with a fellowship from the Coordenação de Aperfeiçoamento de Pessoal de Nivel Superior (CAPES). L.M. Melo conducted her post-doctoral study under the auspices of PNPD/CAPES and V.J.F. Freitas is a 1D fellow of the Conselho Nacional de Desenvolvimento Científico e Tecnológico (CNPq). Dr. A. Leyva helped with the translation and editing of the manuscript.

\section{REFERENCES}

Archer, J.S.; Kennan, W.S.; Gould, M.N; Bremel RD. (1994), Human growth hormone (hGH) secretion in milk of goats after direct transfer of the hGH gene into the mammary gland by using replicationdefective retrovirus vectors. Proc. Natl. Acad. Sci. USA., 91, 6840-6844.

Baguisi, A.; Behboodi, E.; Melican, D.T.; Pollock, J.S.; Destrempes, M.M.; Cammuso, C.; Williams, J.L.; Nims, S.D.; Porter, C.A.; Midura, P.; Palacios, M.J.; Ayres, S.L.; Denniston, R.S.; Hayes, M.L.; Ziomek, C.A.; Meade, H.M.; Godke, R.A.; Gavin, W.G.; Overström, E.W.; Echelard, Y. (1999), Production of goats by somatic cell nuclear transfer. Nat. Biotechnol., 17, 456-461.

Baldassarre, H.; Karatzas, C.N. (2004), Advanced assisted reproduction technologies (ART) in goats. Anim. Reprod. Sci., 82-83, 255-266.

Baldassarre, H.; Wang, B.; Gauthier, M.; Neveu, N.; Lazaris, A.; Karatzas, C.N. (2004a), Effect of GnRH injection timing in the production of pronuclear-stage zygotes used for DNA microinjection. Zygote, 12, 257-261.

Baldassarre, H.; Wang, B.; Keefer, C.L.; Lazaris, A.; Karatzas, C.N. (2004b) State of the art in the production of transgenic. Reprod. Fertil. Dev., 16, 465-470.

Basu, S.; Dunn, A.; Ward, A. (2002), G-CSF: function and modes action (Review). Int. J. Mol. Med., 10, 310.
Behboodi, E.; Ayres, S.L.; Memili, E.; O'Coin, M.; Chen, L.H.; Reggio, B.C.; Landry, A.M.; Gavin, W.G.; Meade, H.M.; Godke, R.A.; Echelard, Y. (2005), Health and reproductive profiles of malaria antigen-producing transgenic goats derived by somatic cell nuclear transfer. Cloning Stem Cells, 7, 107-118.

Betenbaugh, M.J.; Tomiya, N.; Narang, S.; Hsu, J.T.; Lee, Y.C. (2004), Biosynthesis of human-type Nglycans in heterologous systems. Curr. Opin. Struct. Biol., 14, 601-606.

Bösze, Z.; Baranyu, M.; Whitelaw, B.A. (2008), Producing recombinant human milk proteins in the milk of livestock species. Adv. Exp. Med. Biol., 606, 357-393.

Brooks, S.A. (2004), Appropriate glycosylation of recombinant proteins for human use. Implications of choice of expression system. Mol. Biotechnol., 28, 241-254.

Brundige, D.R.; Maga, E.A.; Klasing, K.C.; Murray, J.D. (2008), Lysozyme transgenic goats' milk influences gastrointestinal morphology in young pigs. J. Nutr., 138, 921-926.

Clark, A.J. (1998), The mammary gland as a bioreactor: expression, processing and production of recombinant proteins. J. Mammary Gland. Biol. Neoplasia, 3, 337350.

Cole, E.S.; Higgins, E.; Bernasconi, R.; Garone, L.; Edmunds, T. (1994), Glycosylation patterns of human proteins expressed in transgenic goat milk. J. Cell Biochem., 18, 265.

Darvesh, S.; Hopkins, D.A.; Geula, C. (2003), Neurobiology of butyrylcholinesterase. Nat. Rev. Neurosci., 4, 131-138.

Delitala, G.; Tomasi, P.; Virdis, R. (1988), Neuroendocrine regulation of human growth hormone secretion. Diagnostic and clinical applications. $J$. Endocrinol. Invest., 11, 441-462.

Denman, J., Hayes, M., O’Day, C., Edmunds, T., Bartlett, C., Hirani, S., Ebert, K. M., Gordon, K., \& McPherson, J. M. (1991), Transgenic expression of a variant of human tissue-type plasminogen activator in goat milk: Purification and characterization of the recombinant enzyme. Biotechnology (NY), 9, 839843.

Deutsch, H.F. (1991), Chemistry and biology of alphafetoprotein. Adv. Cancer Res., 56, 253-312.

Dong, X.N.; Chen, Y.H. (2007), Marker vaccine strategies and candidate CSFV marker vaccines. Vaccine 25, 205-230.

Dyck, M.K.; Lacroix, D.; Pothier, F.; Sirard, M.A. (2003), Making recombinant proteins in animals different systems, different applications. Trends. Biotechnol., 21, 394-399. 
Ebert, K.M.; Selgrath, J.P.; DiTullio, P.; Denman, J.; Smith, T.E.; Memon, M.A.; Schindler, J.E.; Monastersky, G.M.; Vitale, J.A.; Gordon, K. (1991), Transgenic production of a variant of human tissuetype plasminogen activator in goat milk: generation of transgenic goats and analysis of expression. Biotechnology (NY), 9, 835-838.

Ebert, K. M.; DiTullio, P.; Barry, C.A.; Schindler, J. E.; Ayres, S. L.; Smith, T. E.; Pellerin, L. J.; Meade, H. M.; Denman, J.; Roberts, B. (1994), Induction of human tissue plasminogen activator in the mammary gland of transgenic goats. Biotechnology (NY), 12, 699-702.

Edmunds, T.; Van Patten, S.M.; Pollock, J.; Hanson, E.; Bernasconi, R.; Higgins, E.; Manavalan, P.; Ziomek, C.; Meade, H.; McPherson, J.M.; Cole, E.S. (1998), Transgenically produced human antithrombin: structural and functional comparison to human plasma-derived anti-thrombin. Blood, 91, 4561-4571.

Fan, W.; Plaut, K.; Bramley, A.J.; Barlow, J.W.; Kerr, D.E. (2002), Adenoviral-mediated transfer of a lysostaphin gene into the goat mammary gland. $J$. Dairy Sci., 85, 1709-1716.

Fan, W.; Plaut, K.; Bramley, A.J.; Barlow, J.W.; Mischler, S.A.; Kerr, D.E. (2004), Persistency of adenoviral-mediated lysostaphin expression in goat mammary glands. J. Dairy Sci., 87, 602-608.

Frade, J.M.; Barde, Y.A. (1998), Nerve growth factor: two receptors, multiple functions. BioEssays, 20, 137 145.

Freitas, V.J.F.; Serova, I.A.; Andreeva, L.E.; LopesJúnior, E.S.; Teixeira, D.I.A.; Cordeiro, M.F.; Rondina, D.; Paula, N.R.; Arruda, I.J.; Verde, J.B.; Dvoriantchikov, G.; Serov, O. (2003), Birth of normal kids after microinjection of pronuclear embryos in a transgenic goat (Capra hircus) production program in Brazil. Genet. Mol. Res., 2, 200-205.

Freitas, V.J.F.; Serova, I.A.; Andreeva, L.E.; Dvoryanchikov, G.A.; Lopes-Junior, E.S.; Teixeira, D.I.A.; Dias, L.P.B.; Avelar, S.R.G.; Moura, R.R.; Melo, L.M.; Pereira, A.F.; Cajazeiras, J.B.; Andrade, L.M.M.; Almeida, K.C.; Sousa, F.C.; Carvalho, A.C.C.; Serov, O.L. (2007), Production of transgenic goat (Capra hircus) with human granulocyte colonystimulating factor (hG-CSF) gene in Brazil. An. Acad. Bras. Cienc., 79, 585-592.

Freitas, V.J.F.; Teixeira, D.I.A.; Melo, L.M.; LopesJunior, E.S.; Moura, R.R.; Pereira, A.F.; Sousa, F.C.; Almeida, K.C.; Avelar, S.R.G.; Cajazeiras, J.B.; Dias, L.P.B.; Dvoryanchikov. G.A.; Andreeva, L.E.; Serova, I.A.; Serov, O.L. (2010), Generation of transgenic naturalized goats producing human granulocyte-colony stimulating factor (hG-CSF) in Brazil. Transgenic Res., 19, 146.

Gordon, K.; Lee, E.; Vitale, J.A.; Smith, A.E.; Westphal, H.; Hennighausen, L. (1987), Production of human tissue plasminogen activator in transgenic mouse milk. Biotechnology (NY), 24, 425-428.
Greene, L.A.; Shooter, E.M. (1980), The nerve growth factor: biochemistry, synthesis, and mechanism of action. Annu. Rev. Neurosci., 3, 353-402.

Han, Z.S.; Li, Q.W.; Zhang, Z.Y.; Xiao, B.; Gao, D.W.; Wu, S.Y.; Li, J.; Zhao, H.W.; Jiang, Z.L.; J.H. (2007), High-level expression of human lactoferrin in the milk of goats by using replication-defective adenoviral vectors. Protein Expr. Purif., 53, 225-231.

Han, Z.; Wu, S.; Li, Q.; Li, J.; Gao, D.; Li, K.; Liu, Z.W.; Zhao, H. (2009), Efficient human growth hormone gene expression in the milk of nontransgenic goats. Folia Biol. (Praha), 55, 17-22.

Hammer, R.E.; Pursel, V.G.; Rexroad, C.E.; Wall, R.J.; Bolt, D.J.; Ebert, K.M.; Palmiter, R.D.; Brinster, R.L. (1985), Production of transgenic rabbits, sheep and pigs by microinjection. Nature, 315, 680-683.

Houdebine, L.M. (2003), From the gene to the transgenic animal. In: Animal transgenesis and cloning. West Sussex: Wiley, pp. 1-32.

Huang, S.; Zhang, K.; Huang, Y.; Chen, M.; Li, H.; Lu, D.; Lu, J.; Chen, Y.; Qiu, X.; Xue, J.; Zeng, Y. (1998), Secretion of biological active human IX protein in the milk of transgenic goats. Chin. Sci. Bull., 43, 1317-1319.

Huang, Y.J.; Huang, Y.; Baldassarre, H.; Wang, B.; Lazaris, A.; Leduc, M.; Bilodeau, A.S.; Bellemare, A.; Côté, M.; Herskovits. P.; Touati. M.; Turcotte, C.; Valeanu, L.; Lemée, N.; Wilgus, H.; Bégin, I.; Bhatia, B.; Rao, K.; Neveu, N.; Brochu, E.; Pierson, J.; Hockley, D.K.; Cerasoli, D.M.; Lenz, D.E.; Karatzas, C.N.; Langermann, S. (2007), Recombinant human butyrylcholinesterase from milk of transgenic animals to protect against organophosphate poisoning. Proc. Natl. Acad. Sci. USA., 104, 13603-13608.

Karatzas, C.N.; Zhou, J.F.; Huang, Y.; Duguay, F.; Chretien, N.; Bhatia, B.; Bilodeau, A.; Keyston, R.; Tao, T.; Keefer, C.L.; Wang, B.; Baldassare, H.; Lazaris, A. (1999), Production of recombinant spider silk $\left(\right.$ BioSteel $\left.^{\circledR}\right)$ in the milk of transgenic animals. Transgenic Res., 8, 476-477.

Keefer, C.L. (2004), Production of bioproducts through the use of transgenic animal models. Anim. Reprod. Sci., 82-83, 5-12.

Kling, J. (2009), First US approval for a transgenic animal drug. Nat. Biotechnol., 27, 302-303.

Ko, J.H.; Lee, C.S.; Kim, K.H.; Pang, M.G.; Koo, J.S.; Fang, N.; Koo, D.B.; Oh, K.B.; Youn, W.S.; Zheng, G.D.; Park, J.S.; Kim, S.J.; Han, Y.M.; Choi, I.Y.; Lim, J.; Shin, S.T.; Jin, S.W.; Lee. K.K.; Yoo, O.J. (2000), Production of biologicaly active human granulocyte colony-stimulating factor in the milk of transgenic goat. Transgenic Res., 9, 215-222.

Krimpenfort, P.; Rademakers, A.; Eyestone, W.; van der Schans, A.; van den Broek, S.; Kooiman, P.; Kootwijk, E.; Platenburg, G.; Pieper, F.; Strijker, R.; de Boer, H. (1991), Generation of transgenic dairy cattle using in vitro embryo production. Biotechnology (NY), 9, 844-847. 
Kues, W.A.; Niemann, H. (2004), The contribution of farm animals to human health. Trends Biotechnol., 22, 286-294.

Kumar, J.K. (2008), Lysostaphin: an antistaphylococcal agent. Appl. Microbiol. Biotechnol., 80, 555-561.

Lappin, T.R.; Maxwell, A.P.; Johnston, P.G. (2002), EPO's alter ego: erythropoietin has multiple actions, Stem Cells, 20, 485-492.

Lee, W.K.; Han, Y.M.; Shin, S.T.; Lee, D.H.; Yoo, O.J.; Lee, K.K. (1997), In vitro development of DNAinjected embryos co-cultured with goat oviduct epithelial cells in Korean native goats (Capra hircus aegagrus). Theriogenology, 47, 1115-1123.

Lee, C.S.; Lee, D.S.; Fang, N.Z.; Oh, K.B.; Shin, S.T.; Lee, K.K. (2006), Integration and expression of goat $\beta$-casein/hGH hybrid gene in a transgenic goat. Reprod. Dev. Biol., 30, 293-299.

Lenz, D.E.; Clarkson, E.D.; Schulz, S.M.; Cerasoli, D.M. (2010), Butyrylcholinesterase as a therapeutic drug for protection against percutaneous VX. Chem. Biol. Interact., 187, 249-252 .

Luboń, H.; Paleyanda, R.K.; Velander, W.H.; Drohan, W.N. (1996), Blood proteins from transgenic animal bioreactors. Transfus. Med. Rev., 10, 131-143.

Maga, E.A.; Murray, J.D. (1995), Mammary gland expression of transgenes and the potential for altering the properties of milk. Biotechnology (NY), 13, 14521457.

Maga, E.A.; Cullor, J.S., Smith, W.; Anderson, G.B.; Murray, J.D. (2006a), Human lysozyme expressed in the mammary gland of transgenic dairy goats can inhibit the growth of bacteria that cause mastitis and the cold-spoilage of milk. Foodborne Pathog. Dis., 3, 384-392.

Maga, E.A.; Shoemaker, C.F.; Rowe, J.D.; Bondurant, R.H.; Anderson, G.B.; Murray, J.D. (2006b), Production and processing of milk from transgenic goats expressing human lysozyme in the mammary gland. J. Dairy. Sci., 89, 518-524.

Meade, H.M.; Echelard, Y.; Ziomek, C.A.; Young, M.W.; Harvey, M.; Cole, E.S.; Groet, S.; Smith, T.E.; Curling, J.M. (1999), Expression of recombinant proteins in the milk of transgenic animals. In: Gene expression systems, ed. J. Fernandez; J. Hoeffler, London, Academic Press, pp. 399-427.

Montesino, R.; Toledo, J.R. (2006), La glândula mamaria: biofábrica para la producción de proteínas recombinantes. Biotecnol. Aplic., 23, 271-278.

Murano, G.; Williams, L.; Andersson, M. (1980), Some properties of antithrombin III and its concentration in human plasma. Thromb. Res., 18, 259.

Palmiter, R.D.; Brinster, R.L.; Hammer, R.E.; Trumbauer, M.E.; Rosenfeld, M.G.; Birnberg, N.C.; Evans, R.M. (1982), Dramatic growth of mice that develop from eggs microinjected with metallothionein-growth hormone fusion genes. Nature, 16, 611-615.
Park, Y.; Juárez, M.; Ramos. M.; Haenlein, G. (2007), Physico-chemical characteristics of goat and sheep milk. Small Rumin. Res., 68, 88-113.

Parker, M.H.; Birck-Wilson, E.; Allard, G.; Masiello, N.; Day, M.; Murphy, K.P.; Paragas, V.; Silver, S.; Moody, M.D. (2004), Purification and characterization of a recombinant version of human alpha-fetoprotein expressed in the milk of transgenic goats. Protein Expr. Purif., 38, 177-183.

Pesqueiro, J.B.; Baptista, H.Á.; Motta, F.L.T.; Oliveira, S.M. (2007), Aplicações dos animais transgênicos. Scientific Amer. Bras., 56, 78-85.

Pollock, D.P.; Kutzko, J.P.; Birck-Wilson, E.; Williams, J.L.; Echelard, Y.; Meade, H.M. (1999), Transgenic milk as a method for the production of recombinant antibodies. J. Immunol. Methods., 231, 147-157.

Quinsey, N.S.; Greedy, A.L.; Bottomley, S.P.; Whisstock, J.C., Pike, R.N. (2004), Antithrombin: in control of coagulation. Int. J. Biochem. Cell. Biol., 36, 386-389.

Raju, T.S. (2003), Glycosylation variations with expression systems and their impact on biological activity of therapeutic immunoglobulins. Bioprocess Int., 1, 44-54.

Rosen, J.M.; Li, S.; Raught, B.; Hadsell, D. (1996), The mammary gland as a bioreactor: factors regulating the efficient expression of milk protein-based transgenes. Am. J. Clin. Nutr., 63, 627-632.

Sánchez, O.; Toledo, J.R.; Rodríguez, M.P.; Castro, F.O. (2004), Adenoviral vector mediates high expression levels of human growth hormone in the milk of mice and goats. J. Biotechnol., 114, 89-97.

Schanbancher, F.L.; Amstutz, M.D. (1997), Direct transfection of mammary gland: opportunities for modification of mammary function and the production, composition and qualities of milk. In: Milk Composition, Production, and Biotechnology, ed. R.A.S. Welch. New York: CAB International, p. 243-264.

Schmidt, C. (2006), Belated approval of first recombinant protein from animal. Nat. Biotechnol., 24, 877.

Simmons, J.P.; McClenaghan, M.; Clark, A.J. (1987), Alteration of the quality of milk by expression of sheep beta-lactoglobulin in transgenic mice. Nature, 328, 530-532.

Stowers, A.W.; Chen, L.H.; Zhang, Y.; Kennedy, M.C.; Zou, L.; Lambert, L.; Rice, T.J.; Kaslow, D.C.; Saul, A.; Long, C.A.; Meade, H.; Miller. L.H. (2002), A recombinant vaccine expressed in the milk of transgenic mice protects Aotus monkeys from a lethal challenge with Plasmodium falciparum. Proc. Natl. Acad. Sci. USA, 99, 339-44.

Swanson, B.O.; Anderson, S.P.; DiGiovine, C.; Ross, R.N.; Dorsey, J.P. (2009), The evolution of complex biomaterial performance: The case of spider silk. Integr. Comp. Biol., 49, 21-31. 
Toledo, J.R.; Sánchez, O.; Seguí, R.M.; García, G.; Montañez, M.; Zamora, P.A.; Rodríguez, M.P.; Cremata, J.A. (2006), High expression level of recombinant human erythropoietin in the milk of nontransgenic goats. J. Biotechnol., 17, 225-235.

Toledo, J.R.; Sánchez, O.; Montesino, R.; Farnos, O.; Rodríguez, M.P.; Alfonso, P.; Oramas, N.; Rodríguez, E.; Santana, E.; Veja, E.; Ganges, L.; Frias, M.T.; Cremata, J.; Barrera, M. (2008), Highly protective E2-CSFV vaccine candidate produced in the mammary gland of adenoviral transducer goats. $J$. Biotechnol., 133, 370-376.

Varadhachary, A.; Wolf, J.S.; Petrak, K.; O'Malley, B.W.Jr.; Spadaro, M.; Curcio, C.; Forni, G.; Pericle, F. (2004), Oral lactoferrin inhibits growth of established tumors and potentiates conventional chemotherapy. Int. J. Cancer., 111, 398-403.

Welte, K.; Gabrilove, J.; Bronchud, M.H.; Platzer, E.; Morstyn, G. (1996), Filgrastim (r-metHuG-CSF): the first 10 years. Blood, 88, 1907-1929.

Xiao, B.; Li, Q.; Feng, B.; Han, Z.; Gao, D.; Zhao, R.; Li, J.; Li, K.; Zhi, X.; Yang, H.; Liu, Z. (2009), Expression of recombinant human nerve growth factor beta in milk of goats by recombinant replication-defective adenovirus. Appl. Biochem. Biotechnol., 157, 357-366.
Yang, H.; Li, Q.W.; Han, Z.S.; Hu, J.H.; Li, W.Y.; Liu, Z.B. (2009), Recombinant human antithrombin expressed in the milk of non-transgenic goats exhibits high efficiency on rat DIC model. J. Thromb. Thrombolysis, 4, 449-457.

Zhang, K.; Wang, H.; Bao, Y.; Lu, D.; Xue, J.; Qiu, X.; Huang, S.; Huang, Y.; Li, B.; Li, H.; Zeng, Y. (1997), Human clotting factor IX (hF IX) secretion in goat milk after direct transfer with hF IX minigene into mammary gland by using retroviral vectors. Chin. Sci. Bull., 42, 1308-1313.

Zhang, J.; Li, L.; Cai ,Y.; Xu, X.; Chen, J.; Wu, Y.; Yu, H.; Yu, G.; Liu, S.; Zhang, A.; Chen, J.; Cheng, G. (2008), Expression of active recombinant human lactoferrin in the milk of transgenic goats. Protein Expr. Purif., 57, 127-135.

Zhou, Q.; Kyazike, J.; Echelard, Y.; Meade, H.M.; Higgins, E.; Cole, E.S.; Edmunds, T. (2005), Effect of genetic background on glycosylation heterogeneity in human antithrombin produced in the mammary gland of transgenic goats. J.Biotechnol., 117, 57-72.

Received: September 17, 2010; Revised: December 15, 2010; Accepted: April 27, 2011. 